\title{
Urban Agriculture: Search for Agricultural Practice in Urbanized Rural Areas
}

\author{
Celile Özçiçek Dölekoğlu ${ }^{1}$, Sema Gün²*
}

${ }^{1}$ Business Administration, Faculty of Business, Adana Science and Technology University, 01250 Adana, Turkey

${ }^{2}$ Department of Agricultural Economics, Faculty of Agriculture, Ankara University, 06110 Ankara, Turkey

\section{A R T I C LE IN F O}

\section{Review Article}

Received 22 July 2017

Accepted 12 October 2017

Keywords:

Urban agriculture

Urban environment

Food security

City farm

Sustainability

*Corresponding Author:

E-mail: gun@agri.ankara.edu.tr

\begin{abstract}
A B S T R A C T
Rapid urbanization in developing countries involves unplanned migration, unemployment and poverty. The steady shrinking of rural areas and the use of agricultural land for other purposes are progressively increasing the pressure on natural resources. This development on the one hand increases the risk to food security, and on the other triggers climate change. The rural population who migrate to the cities or who are absorbed into urban areas continue their agricultural activities in the urban in order to provide themselves with an income or to maintain their food security. In the big cities of the developed world, contact with nature is kept by means of hobby gardens, recreational areas and urban and suburban plant and animal farming, and creative ideas such as roof gardens can be found. This development, known as urban agriculture, is practiced by 800 million people in the world. Urban agriculture has many economic, social and environmental benefits, but it may also have risks and adverse effects. In this study, the developments in this area in Turkey and the world are presented, and all aspects of its effects and outcomes are discussed.
\end{abstract}

DOI: https://doi.org/10.24925/turjaf.v5i12.1461-1469.1432

\section{Introduction}

The world is undergoing a progressive urbanization of life and settlement styles. In 2014, 53.6\% of the total world population lived in cities, and this proportion is expected to rise to $66 \%$ by 2050 (UN, 2014). In this process, it is predicted that the development of urbanization in developing countries will be faster $(85.4 \%)$, and it will approach the proportion of urbanization in developed countries $(86.7 \%)$. According to the World Bank predictions of 2011, more than $90 \%$ of urban growth is taking place in developing countries, and each year the population of urban areas increases by 70 million (UN-HABITAT, 2014). In these countries, one in three of the urban population is living in shanty settlements or slums (UN-HABITAT, 2013). In 2000, 776.7 million people were living in slums, and this number had risen to 827.6 million by 2010 (UNHABITAT, 2010a). This means that on average 55 million people a year are added to the urban slum population. In sub-Saharan Africa more than half (61.7\%) of the urban population are living in slums, while in Latin America and the Caribbean this number is $23.5 \%$, and in Asian cities, which are home to half of the world's urban population, the slum population approaches $60.6 \%$ (UN-
HABITAT, 2010b). In South Asia and sub-Saharan Africa, which are the two poorest parts of the globe, the urban population is expected to approximately double between 2015 and 2035 (UN, 2014). Half of the population of Asia is expected to be living in urban areas by 2020 , while Africa is expected to reach a proportion of $50 \%$ urbanization only by 2035 (ECOSOC, 2014). Africa is the least urbanized continent but is rapidly urbanizing along with Asia; in its developing countries, urbanization is predicted to accelerate and also the urbanization balance is expected to move regionally towards that of less developed areas.

On a worldwide scale, as well as the economic difficulties of the unknown speed of future growth of industry, services and employment, urbanization brings problems of a high level of unregistered urban activity, social and spatial inequalities, urban spread, unplanned urbanization, weak urban-rural links and socio-spatial difficulties of such things as the increasing spatial scale of cities and their ecological footprints. The reduction in natural resources along with the increasing world population means that the emerging crisis in food prices is more felt in areas experiencing rapid urbanization. 
In developing countries, a quarter of the poor population lives in urban areas, and because poor people urbanize more rapidly than the population as a whole, poverty is being progressively urbanized (Chen and Ravallion, 2007). The urban poor are becoming more and more distinct within the urban population; they are becoming net buyers of food and they are dependent on their local food markets for their consumption. The increase in the world's population and the situation created by the use of natural resources makes it difficult to solve the demographic problems created by climatic and environmental changes. One solution is urban agriculture. Urban agriculture is seen as a chance for an improvement in food supply and health conditions, a local economy, social cohesion and a sustainable environment (Orsini et al., 2013).

Because of the difficulty of maintaining the traditional lifestyle in areas initially defined as urban and of access to food products, urban agriculture has recently been practiced in order to maintain food security and to preserve sensitivity for natural life and the urban's wild places. Urban agriculture is a system which is practiced throughout the world, and its share of the global food sector is approximately 25-30\% (Orsini et al., 2013). According to 1993 data, 800 million people were working in urban agriculture, 200 million of whom were producing for the market and 150 million were working full time in agricultural production (Smit et al., 2001). It is estimated that 230 million urban dwellers in Africa and 130 million in Latin America practice gardening, producing not only for their families but also to provide an income (FAO, 2010). Because systems of urban agriculture have various differing characteristics relating to local, socio-economic, geographical and political conditions, urban agriculture varies throughout the world (Stewart et al., 2013).

In this study, the extent, importance, advantages and limitations of urban agriculture as it has been spreading as a result of encouragement or personal preferences in many countries is considered, and the applicability of this method in the world in general and in Turkey, which carries the same risks, is discussed.

\section{Urban Agriculture}

Problems arising with regard to adequate, reliable and continuous access to food increase more in areas which are experiencing rapid urbanization. It has not yet been realized by many societies that food security is in danger and that this danger will increase. Practices brought to life in efforts to preserve nature, seen as the fantasies of small groups, are sometimes taken up by individuals or organizations. One of these is the practice known as urban agriculture or urban gardening. Urban agriculture includes house gardens, hobby gardens and tree and seed nurseries, set up in public areas (roadsides or public gardens), institutional areas (the gardens of schools, hospitals, factories and workplaces), balconies, roofs and backyard henhouses or animal houses for small scale production for family consumption or the market. In cities with poverty pressure, agriculture is practiced on small plots, by the roadside, in areas with electric cables, in the gardens of educational and administrative institutions, and on riverbanks (Simatele and Binns, 2008). Urban and suburban agriculture covers a wide range of plant products (grain, green vegetables, fruit, fungi and root vegetables), animal products (chickens, rabbits, goats, sheep, cattle, fish, etc.), and non-food products such as ornamental plants and medicinal or aromatic plants (FAO, 2007). Urban agriculture is opportunistic: it is carried on using human creativity in spite of institutional, legal and social restrictions or with little support on roofs, window sills, empty lots, and by the side of roads and railways, in other words in the centers of cities (Mougeot, 2006). Urban agriculture "is a sector which produces, processes and distributes food in or around a town, urban or metropolis, contributing to the consolidation of the urban's economic, social and ecological systems, making use of the urban's own local resources, and influencing the urban's food security, healthy nutrition and poverty levels" (Mougeot, 2000).

Urban agriculture is practiced in most countries by two groups, traditional farmers living in the urban and poor people who have recently moved to the urban area. Another very small group consists of people carrying out agricultural activities for their own consumption for health or as a hobby or a popular lifestyle choice. The model which emerges is a relatively simple and selfsufficient village economy in the big cities, depending on a small exchange of goods (IDRC, 1994). Urban agriculture for this reason continues to exist as a permanent and dynamic part of the urban socio-economic and ecological system using urban resources.

Urban agriculture plays an important role in ensuring food security, but it mostly remains an informal sector which is not fully integrated into agricultural policies and city planning. In many places, one of the most significant problems to do with urban agriculture is a lack of numerical data on its extent and permanence, as these are variable. At the same time, different arrangements have been made for the urban's local needs, and from the feedback from citizens and relevant groups. There is a difference between the potential contribution of urban agriculture to food security in developed and developing countries, and it is practiced with different purposes and by different means (Table 1 ).

Urban agriculture represents a strategy and an opportunity for encouraging local production in the food chain, and to obtain positive externality. Also, it provides an opportunity to support economic vitality and sustainability in cities, to benefit from greater competitive strength and to encourage the effective use and evaluation of resources for local administrations to set up their own versions (Requier-Desjardins et al., 2003). The popularity of urban agriculture is increasing in the cities of many countries such as Australia, Canada, the USA, the UK, France and New Zealand. Different places including urban lots, windows, roofs, basements, walls, recreation areas and roadsides are being used to grow things. Most of these places functions as communal gardens. In spite of its increasing popularity, urban agriculture is only practiced by a very small percentage of the populations of these cities. The North America Urban Agriculture Committee estimates that urban areas provide for only $5 \%$ of urban food consumption (Corbould, 2013). 
Table 1 National and regional differences in the practice of urban agriculture

\begin{tabular}{|c|c|c|}
\hline Urban agriculture & Developed countries/regions & Developing countries/regions \\
\hline Purpose & $\begin{array}{l}\text { Demand for healthy food } \\
\text { To provide an income }\end{array}$ & $\begin{array}{l}\text { Food security } \\
\text { To provide an income }\end{array}$ \\
\hline Producers & Land owners, entrepreneurs & $\begin{array}{l}\text { Urban poor } \\
\text { Migrants from rural areas }\end{array}$ \\
\hline Scale & Variable & Small \\
\hline Location & $\begin{array}{l}\text { House gardens, public gardens, urban farms, } \\
\text { institution gardens }\end{array}$ & $\begin{array}{l}\text { House gardens, empty spaces, river } \\
\text { banks, public areas }\end{array}$ \\
\hline Production & Vegetables, fruit, animals, ornamental plants & Vegetables, fruit, animals \\
\hline Marketing & Own consumption, sale & Own consumption, sale \\
\hline Main problems & $\begin{array}{l}\text { Access to information } \\
\text { Inspection and control } \\
\text { High cost } \\
\text { Storage, processing } \\
\text { Shortage of soil } \\
\text { Security and esthetic cost } \\
\end{array}$ & $\begin{array}{l}\text { Unauthorized production } \\
\text { Preservation of product } \\
\text { Pollution }\end{array}$ \\
\hline Responsibility & $\begin{array}{l}\text { Local administrations, public institutions, voluntary } \\
\text { organizations }\end{array}$ & $\begin{array}{l}\text { Local administrations, public } \\
\text { institutions }\end{array}$ \\
\hline Results & $\begin{array}{l}\text { Sustainable urban } \\
\text { Balanced nutrition }\end{array}$ & $\begin{array}{l}\text { Adequate and balanced nutrition } \\
\text { Reduction in urban poverty }\end{array}$ \\
\hline Support & $\begin{array}{l}\text { Agricultural education } \\
\text { Long-term rental agreements } \\
\text { Reduction in real estate tax } \\
\text { Addition of urban agriculture areas to city planning } \\
\text { Planning housing estate green areas as gardens } \\
\text { Ease of entry to local and district markets }\end{array}$ & $\begin{array}{l}\text { Setting aside empty areas for agriculture } \\
\text { Developing a healthy environment and } \\
\text { infrastructure } \\
\text { Ease of entry to local and district } \\
\text { markets }\end{array}$ \\
\hline
\end{tabular}

Some cities in more developed countries have produced plans and urban agriculture laws for sustainable food production in city centers. For example, municipality policies in California have been updated to make urban agriculture easier and landowners can benefit from a tax reduction of at least five years in return for using their land for agriculture (Anon., 2013a). In Chicago in 2011, support was received for a planning law which recognized the possibility of urban agriculture within the city limits (Silverman and Bolin, 2014). In 2013, this urban agriculture law and a city plan focused on local food production in the city making use of lots left empty by the falling population were put into operation (Pothukuchi, 2015).

In developing countries, urban agriculture has shown a different path to development which is more directed towards the grower's own consumption. However, neither the significance of the capacity of urban agriculture in the market nor its economic value are inconsiderable. Studies have shown that in these countries market-focused smallscale urban agriculture is more profitable than small-scale agricultural production in rural areas and that it provides an income in excess of the minimum wage. Proximity to urban consumers provides comparative advantages in transport, packaging and storage. Urban producers can achieve a price $50-75 \%$ of the retail price of the marketing system, while this proportion falls to $15-40 \%$ in rural areas (Smit et al., 2001).

\section{Positive Outcomes of Urban Agriculture}

Urban agriculture presents effective solutions on the topic of food security and nutrition for the population of cities and their surroundings in the process of rapid urbanization in developing and developing countries. On the world market, between 100 and 200 million urban farmers have a positive economic effect by providing fresh garden produce to the city markets and thus contributing to food security (Orsini et al., 2013). In this way, the consumption of local products is among the recommended methods of reducing food wastage. Urban agriculture also provides an income with the sale of excess production, reducing expenditure on in-family consumption. In developing countries, the cost of urban nutrition is higher than in rural areas. Food losses can be as high as $35 \%$ for perishable food products, and transport costs can reach $90 \%$ of the general food marketing margin (Argenti, 2000).

Food production in cities is mostly a response of the urban poor to insufficient, irregular and unreliable access to food and to a lack of buying power. When it is considered that $50-70 \%$ of the income of the urban poor is spent on food (WORLDBANK, 2012), it is seen that urban agriculture increases their food security by securing a healthy and plentiful alternative for bought foods, especially for poor families. It has been found that poor families practicing urban agriculture have greater food security, follow a more balanced diet throughout the year, and are able to use their savings on food purchases to buy other foodstuffs, and that their children are healthier and better nourished (Corbould, 2013). In urban areas, the production of animal products for sale is a rapidly growing sector and constitutes $34 \%$ of meat production, and approximately $70 \%$ of world egg production takes place in urban areas (Marras, 2014). In Hanoi, Vietnam, $80 \%$ of fresh vegetables and $40 \%$ of eggs are produced by 
urban agriculture (Corbould, 2013). In cities like Harare, where the poverty rate is high, the fact that people have control of food sources by producing vegetables themselves is important for facing shortages and hunger when access to imported food is unexpectedly cut (Kisner, 2008). In Sofia, approximately half of families produce fruit, vegetables and herbs at home; over $90 \%$ process home produced or bought products in various ways for long-term use, and $14 \%$ of families are selfsufficient by the use of these methods (Yoveva et al., 2000). Areas which can be counted as suitable for use as agricultural land are to be found within city limits. Most urban poor families in Kenya are unable to feed themselves adequately from their incomes, and so they carry on urban agriculture by the roadside or in other empty public spaces. Farming is an economic necessity for these families, and this necessity is a primary motivating factor in their behavior to meet their basic needs (Korir et al., 2015).

Urban agriculture has ecological advantages in turning urban waste into fertilizer, improving urban biodiversity and air quality, and generally reducing the effect on the environment of the distribution and storing of food. Urban agriculture enables a urban's organic waste to be used in a productive way. In South America, cities routinely recycle their organic waste and offer it as garden compost. Successful examples of this are increasing throughout the world, and the possible negative environmental aspects of urban or suburban agriculture are being solved in this way. In the Ethiopian capital Addis Ababa, a company collects 3.5 tons of organic waste daily and converts it into approximately two tons of high quality fertilizer (ILO, 2013). In Cuba, chemical fertilizers are forbidden in a national plan of urban gardening, and the use of organic fertilizer is encouraged instead (Altieri et al., 1999). Also, obtaining food products from the city reduces the need for transport to the urban from distant rural areas, thus saving fuel, reducing carbon dioxide and other air pollution emissions, and playing a role in reducing the heat island effect. For example, it has been reported that in Cairo, houses with vegetables planted on the roof are seven degrees cooler than neighboring buildings (FAO, 2010). In Argentina, areas where urban agriculture is practiced and where there are many trees are cooler both day and night than the city center and places where plant cover is sparse, and this supports the use of urban agriculture as an urban policy to reduce climate change (Coronel et al., 2015).

It is true that urban agriculture constitutes a small part of the overall agricultural economy, and although smallscale urban agriculture is becoming more widespread, this sector represents only a small percentage of total food supply. However, this production method often has an economic value which is disproportionate to its size. This value results partly from more intensive farming techniques and because of direct sales or a minimal level of intermediaries. Producers in urban areas have an additional advantage in that they have a wide consumer base, making direct marketing easier. At the beginning of the 1990s, they had the highest self-employed earnings in small-scale businesses in Nairobi, and provided the third highest earnings in Kenya (House et al., 1993).
Urban agriculture can generally be seen as a means of deriving economic value from empty or little-used land. For example, money can be made from the use of the roofs of buildings for this purpose and from renting out spaces not used for any other purpose. It is important to consider the indirect economic advantages of urban agriculture. Among these are an increase in the prices of property surrounding the community gardens and an increase in taxation revenues in these areas (Viocu and Been, 2008). The contribution of urban agriculture to planned initiatives by local administrations is high. The success of gardening on Peru's arid coastline, by encouraging many city administrations to create green belts, has helped to stabilize sensitive areas such as slopes and river banks and to prevent the building of unsafe housing in these areas (FAO, 2010).

The social benefits of urban agriculture are just as important as the economic and environmental benefits, if not as a numerical statement. Some of these benefits can be listed as the closeness of society to nature, the effect of healthy eating on forming a healthy society, the reduction of inequality in the role of women in the family, and a physical and mental healing effect. Urban agriculture has been effective in creating awareness among the urban population of healthy eating and reducing obesity, and in creating behavior changes in school-age children by increasing this awareness by school gardening. Sociologically, urban agriculture also helps the $65 \%$ of urban farmers who are women both to increase their social engagement and to reduce gender inequalities (Orsini et al., 2013). Also, plant therapy, defined as a process using plants and gardening activities to develop people's social, educational, psychological and physical rapport and in this way strengthening their bodies, minds and spirits, provides social benefits. It is used as treatment because as well as helping people to accept responsibility it helps social development and the use of muscles and coordination, and increases balance and strength (Arslan and Katipoğlu, 2011). Researchers have shown that living close to green areas in cities lowers blood pressure and stress and thus improves physical and mental health (FAO, 2016). Through urban agriculture, people remain in constant contact with nature and learn the vital role of the ecosystem directly. A relationship can be set up between young people, the natural environment and their roots in the countryside through the transfer of information between generations in urban areas.

Urban agriculture is a chance for a thorough revision of food supplies, health conditions, the local economy, social cohesion and environmental sustainability. It is a practice with great benefits because it is carried on the three bases, economic, social and environmental, of sustainability in post-industrialization and developing cities (Ackerman et al., 2014). Urban agriculture in less developed and developing countries present effective solutions for urban populations and the environment in terms of food security and nutrition in the process of rapid urbanization. It is thought that it contributes to improving the urban environment and reducing the production pressure on agricultural land, to easing the transportation of food to the urban poor, and to creating a potential source of income in urban areas. 


\section{Areas of Disadvantage and Key Points of Urban Agriculture}

Just as urban agriculture has positive effects in economic, social, political and technological terms, it also has potential disadvantages with its increasing driving force, and its risks to urban health and negative effects on the environment are discussed. It is worth considering these negative points. For example, the use of waste water can lead to the production of unhealthy food, or intensive irrigation can result in the spread of malaria and waterborne diseases. It can threaten the limited water sources of cities. The intensive use of soil and the use of fertilizers and agricultural chemicals can cause an unhealthy environment for the urban population.

Although many poor families derive benefit from urban agriculture, many cities do not have a legal framework encompassing the public health, administrative and social aspects of urban agriculture. This kind of farming is generally ignored by the authorities, and an uncontrolled system has resulted. In particular, the uncontrolled and risky practice of agriculture which is the only activity known to those who migrate from the countryside brings many problems with it. This may cause an increase in food insecurity and a reduction in productivity and the adoption by farmers of sustainable agricultural practices. In Zimbabwe, this insecurity discouraged farmers from planting long-term crops, and prompted them to grow low yield crops which did not appear edible, which could be hidden from the police and from potential thieves (Corbould, 2013). Because setting up urban agriculture needs significant resources, many developing countries lack the necessary infrastructure and institutional framework to provide these conditions.

Because urban agriculture is generally practiced especially in low-income countries on "unused" empty public land, it is conducted at low cost. For example, rather than setting up expensive irrigation systems, farmers generally make use of waste water, which is dirty and can pose a threat to the health of consumers. This concerns not only human health, but the pollution of groundwater and soil. Urban agriculture needs large amounts of water and fertilizer, and so is in competition for water and other natural resources because these are expensive (Orsini et al., 2013). The use of chemicals may increase in urban agriculture in connection with intensity of production. Smaller amounts of chemicals are used for home consumption, but excessive amounts may be used in production for the market. Products grown using waste water are particularly risky. However, waste water of domestic origin which has been sufficiently purified for re-use in agriculture can provide plants with most of the nutrients they need. For example, in Gaza and the West Bank, the FAO has supported the setting up of low-cost water purification systems to irrigate gardens with water from kitchens and showers (FAO, 2010). As competition for urban water intensifies, it is necessary to include the recycling of waste water for garden plants in urban planning. In urban areas, air and water pollution, which are rapidly increasing and are more and more difficult to control, are a problem. In China, there has been a loss of productivity of $15 \%$ as a result of a reduction in the area of urban land used for growing vegetables and irrigation with waste water (Guang, 1997).

Urban animal production can also cause problems. In Darussalam it is thought that tetanus originated from chemical contamination because of the inappropriate disposal of animal carcasses and the excessive use of antibiotics and agricultural chemicals (Beach, 2013). The density of the urban population and the number of animals and limitations in the production area according to the species of animal will be effective in solving health problems. Considering the potential benefits of urban agriculture, decision makers in urban planning must take account of farmers' use of land, secure access to clean irrigation water, and protect public health (Beach, 2013).

Urban agriculture is also threatened by urban spread. Future production levels are unpredictable because of the spread of cities on to agricultural land (Corbould, 2013). Because of increased urbanization, there is a reduction in peri-urban farms and empty land for new buildings and the transportation network. These developments push farmers from cultivable land to land of low fertility and productive capacity.

In developed countries, a shortage of urban production land and a lack of economic support limit production growth. Also, storage, processing, distribution and the provision of fresh food to the retail market are difficulties for the urban farmer. Very few urban farmers have these facilities. One of the difficulties in the practice of agriculture in cities is the low possibility of competing when compared with other economic activities. However, it is true that urban areas allow the intensive production of foods which can be grown under local ecological conditions and which spoil in a short time and their consumption where they are grown. Another barrier to the spread of urban agriculture is the high cost. Although transport costs are low, high startup costs, expensive urban land and high labor costs make urban agriculture expensive. In mostly developed countries, most of the population do not have the opportunity to provide themselves with nutrition from urban agriculture. In the current situation, urban agriculture will remain a spare time activity rather than an alternative source of food.

The contribution of urban agriculture to food security varies from country to country. It is high in countries where the level of poverty is high. For countries with limited potential, it is not advocated as an effective method of achieving food security. It is reported that in the Netherlands food production in urban areas accounts for only $0.0018 \%$ of food consumption (Monaco et al., 2017). It is estimated that in New York City between 16 200 and 23200 ha of land is needed for the production of fresh fruit and vegetables of urban origin (Ackerman et al., 2012). Solutions to the shortage of land can be found in alternative farming methods. Vertical gardens, growing in water and soil-free farming have the capacity to increase production without the need for large areas of land. 
The Legal Situation for Urban Agriculture in Turkey and the Conditions under which it can be practiced

According to statistics, over $70 \%$ of the population of Turkey lives in cities. Urban areas in Turkey display a urban model which has developed in such a way that there are no urban open spaces, causing ecological breakdown, with people moving from the countryside to the city in an unplanned way, not belonging to urban culture, in an accumulation of apartment buildings, and with the soil person relationship destroyed. In the use of agricultural land for other purposes, urban use comes second after industrial use (Topçu, 2012). The rapid growth of urban areas, occurring within a framework of town planning including farming and pasture areas, allows agricultural production in these areas with the farming culture brought by the population migrating from the villages to the urban. High food prices and relatively low incomes encourage this population to produce in particular for their own consumption.

In Turkey, although there are many ideas and institutions relating to the environment and agriculture, in the area of urban agriculture there is no management or legal regulation. It is seen that in agricultural activities conducted in cities crop production and animal farming are assessed separately and plant production is taken in a similar way as traditional. The practice of growing plants in the gardens of houses and in empty agricultural areas has become famous in some cities under various names such as Kazakiçi gardens, Yedikule gardens, or Kuzguncuk garden. Some of these areas have a long history and have not been able to maintain their existence when land values rose as the city expanded. Urban animal farming is an activity which is banned in Turkey, and legislation on this topic goes back to the 1930s. Law No 1593, the Law on Public Health, went into operation on 6 May 1930, and gave the government the duty of improving the country's health conditions, combatting all diseases or other factors which could affect public health, raising the next generation in a healthy way and allowing people to benefit from medical and social aid (Article 1). The article 4 of the same law provides the authority for all municipalities and provincial and local administrations to take necessary measures for healthy living in the provinces. The article 246 of the law states "In towns with a population of more than twenty thousand it is forbidden to have animal houses on the streets or in areas designated by the municipality", clearly restricting urban animal keeping. As well as this prohibition, the article 20 of the same law gave municipalities the duty of righting the damage caused by non-compliance with these decisions and "removing factors which damage public health in public areas". The law authorized committees set up at provincial and district level to improve health conditions and to remove existing negative conditions (Article 27). The article 266 of the law provides for the municipalities to carry out control and inspection by means of a local police force.

The article 8 of Law No 2872 on the environment is concerned with those who, when there is a possibility of pollution, are responsible for taking the necessary measures to prevent pollution, stop pollution and its source when it occurs, and remove or reduce the effects of pollution. The article 12 of the law states that authority for inspecting whether the law is adhered to rests with the Ministry of the Environment, or when necessary, it can be handed over by the Ministry to the provincial administration, to municipalities which set up environmental inspection units or other institutions as seen suitable by the Ministry. It allows the Local Environmental Committees set up for this purpose to make decisions regarding urban agriculture on protecting and improving the environment, taking the necessary decisions to prevent pollution, preparing programs to carry out the decisions and measures at province level and carrying them out within a set period, determining the establishments or businesses which are or could be sources of pollution, examining and evaluating the work or operations conducted, and taking the necessary measures (Anon., 2013b).

It can be seen from the information given above that animal keeping activities in urban areas are prohibited in Turkey. These regulations are being enforced by the various police forces set up by the municipalities. These administrations prohibit any kind of housing or shelter for animal keeping, leaving animals on the streets, leading them around the streets singly or in groups, or grazing them in places such as parks, gardens, building plots, in the grounds of monuments, wooded areas or graveyards. Another regulation covers disturbing the environment by throwing down any kind of animal waste in the open. Bee keeping is forbidden within the urban and placing bees in rural areas with portable or fixed hives in such a way that the bees disturb the environment is also forbidden (Anon., 2017a, b, c). However, when these regulations are examined it can be seen that in some cities municipality committees have given permission for animal keeping in areas set aside for this purpose (Anon., 2017d, e, f). But in spite of these regulations and prohibitions, it is still possible to find backyard chicken keeping, sheep and goat rearing and milk production.

In Turkey, the idea that urban and rural policies are in competition and the destruction of farming areas by urban development have caused farming within the urban to be seen as an unsuitable activity, and for it often to be forbidden. Agricultural land remaining within the urban gains value as building land rather than being preserved for farming, and legal cases are opened to set up the infrastructure for its use for other purposes, showing that there is a demand for turning agricultural land into building land. This being so, Cabinet Decision No $83 / 6122$ which states that such land should not be included in city planning and that its use for agriculture should be maintained even though it falls within municipality boundaries can form a basis for the preservation of these areas for urban agriculture.

Under law No 6360, the urban and provincial boundaries in 30 provinces of Turkey were made the same so that the concepts of urban and rural were unified both in terms of area and administration. Municipalities, which are institutions of urban administration, were given authority in rural areas, and villages were removed as legal entities. However, it is a fact that villages and rural areas, with their particular natural environmental, socioeconomic and social characteristics, are quite different 
from urban areas and cannot be administered within the same management. Considering the experiences of urbanization in Turkey, it was feared that the conversion of these areas into urban land would be accelerated with these administrative changes and it was thought that urban development pressure would increase in agricultural areas as in all-natural areas (Yenigül, 2016). Law No 5216 gives to metropolitan provinces the duties of performing all kinds of activities and services with the aim of securing the protection of the environment, agricultural areas and water catchment areas in accordance with the principles of sustainable development, and law No 6360 authorizes metropolitan and district municipalities to support agriculture and animal rearing. However, some metropolitan municipalities have not gone into details about how the management of rural agriculture by local administrations and the area of authority should be used in this setup, and they formed management units for rural or agricultural services. The agriculture sector is one which is not a natural part of the authority and duties of a municipality. With these laws the metropolitan municipalities on the one hand removed the villages and rural areas, and on the other took on the duties of protecting agricultural land and supporting agriculture (Gün, 2014), but these same municipalities continue to pursue a policy of obstructing agricultural activities in the cities, which are their basic area of authority. As well as being an aspect in support of the municipalities being given authority in rural areas, this process may provide the municipalities with a viewpoint to carry out necessary reforms with regard to the possibility of carrying out agricultural production in urban areas.

\section{Conclusion}

Increasing population, fluctuations in the price of food, climate change, the use of energy for agricultural production, the use of agricultural land for other purposes, poverty, and food waste and loss are basic problems for sustainable natural resources. The expected increase in urban populations and the spread of metropolitan areas demands an expansion in the agricultural sector to meet the high demand for food. On the one hand the use of agricultural land for other purposes caused by rural areas being enclosed in the spreading cities, and on the other the productive rural population becoming net consumers, are increasing pressure on natural resources. The tendency to urbanization in this way gives little hope for a sustainable world without bringing the cities into a more sustainable condition. In general, when the urban heat island effect, air and water pollution, increasing food prices and a higher proportion of poor people, health concerns, lack of economic independence and environmental degradation are accepted as problems specific to those living in cities, excessive consumption of resources and waste have started to progressively affect agricultural land which is well outside urban boundaries and rural society. For this reason, cities have started to again take into account food sources, water sources, environmental waste, energy sources and the environmental sustainability of dense populations, and the conditions reducing the dependence on food over long distances. In this way, even if urban agriculture turns out to be a sustainable method, it needs a large amount of reform.

Most urban agriculture serves a function of supplementing rural agriculture and increasing its effectiveness on the national food supply system. While urban agriculture is developing under its own dynamics in most countries, it does not feature in urban infrastructure, laws and city planning, and most cities do not have a vision for the future in this area. At the same time, it can be seen that this situation has changed in city administrations working with local stakeholder groups and food policy committees. Urban agriculture laws and counselling services create a sense of urban belonging and support urban farmers. Despite the potential advantages and disadvantages of urban farming, when the current policy to support it is considered, it can be seen that there is a need for research and statistical information to understand its effects on urban populations and environments.

There is no certain formula for success in urban agriculture. However, setting up legal provisions, adding regulations concerning urban agriculture to city planning regulations and regulating community gardens, product sales and protection of animals are important steps. Experiences gained in many cities of the world in which urban agriculture laws have been enacted or have been better arranged can be a guide in reducing the risks caused by urban farming in developed countries.

Urban agriculture has the potential to affect the world economy and environmental conditions including climate change and increasing food and fuel prices. Also, it will continue to be practiced in the world in the future as an activity enabling food production, employment and a sustainable city, but for this process to be sustainable there must be city plans and policies, and systems must be put in place to monitor and eliminate possible negative conditions which may appear. Local administrations and city planning units must form management regulations for urban agriculture. In order to achieve integration in the use of urban land by urban agriculture in urban policies and to achieve sustainability in these areas, legal protection, the planning by city planners of a city design such as to protect these areas and the creation of a positive political environment will enable the development of the sector.

\section{References}

Ackerman K, Dahlgren E, Xu X. 2012. Sustainable Urban Agriculture: Confirming Viable Scenarios for Production. Prepared for the New York State Energy Research and Development Authority. https://www.nyserda.ny.gov//media/Files/Publications/Research/Environmental/SustainableUrban-Agriculture.pdf [Accessed:10.06.2017].

Ackerman K, Conard M, Culligan P, Plunz R, Sutto MP, Whittinghill L. 2014. Sustainable food systems for future cities: The potential of urban agriculture. The economic and social review, 45(2);189-206.

Altieri MA, Companioni N, Canizares K, Murphy C, Rosset P, Bourque M, Nicholls CI. 1999.The greening of the "barrios: Urban agriculture for food security in Cuba. Agriculture and Human Values, 16(2); 131-140.

Anonymous 2013a. Assembly Bill No. 551. http://leginfo.legislature.ca.gov/faces/billNavClient.xhtml?bill_i $\mathrm{d}=201320140$ AB551 [Accessed:08.05.2017]. 
Anonymous 2013b. Yüksek Çevre Kurulu ve Mahalli Çevre Kurullarının Çalışma Usul ve Esaslarına İlişkin Yönetmelik. T.C.Resmî Gazete. Sayı : 28727.

Anonymous 2017a. Bursa Büyükşehir Belediyesi Emir ve Yasaklarını Belirleyen Zabıta Yönetmeliği. http://www.bursa.bel.tr/dosyalar/birimek/bursa-buyuksehirbelediyesi--emir-ve-yasaklarini-belirleyen-zabitayonetmeligi.yonetmelik.9KINCOYutH.doc

[Accessed: 01.07.2017]

Anonymous 2017b. Zabita Kabahatler Talimatnamesi. http://www.etimesgut.bel.tr/index.php?Page $=$ Sayfa $\& N o=650$ [Accessed: 01.07.2017].

Anonymous 2017c. Eskişehir Odunpazarı Belediyesi Zabıta uygulama yönetmeliği. http://www.odunpazari.bel.tr/dosya_yoneticisi/Y\%C3\%B6netm elikler/zabita.pdf [Accessed: 01.07.2017].

Anonymous 2017d. Bodrum Belediyesi Zabita Uygulama Yönetmeliği. $\quad \mathrm{http} / /$ bodrum.bel.tr/karardetay/bodrumbelediyesi-zabita-uygulama-yonetmeligi.html [Accessed: 01.07.2017].

Anonymous 2017e. Konya Büyükşehir Belediyesi İdari-Fenni Zabıta Yönetmeliği. http://www.konya.bel.tr/mevzuat/12.pdf [Accessed: 01.07.2017].

Anonymous 2017 f. İzmir Çiğli Belediyesi Zabıta Müdürlüğü Belediye Yasakları Uygulama Yönetmeliği.https://kms.kaysis.gov.tr/Home/Goster/64255?Asp xAutoDetectCookieSupport=1 [Accessed:01.07.2017].

Argenti O. 2000.Feeding The Cities: Food Supply And Distribution Focus 3, Brief 5, Of 10. International Food Policy Research Institute. http://www.ucl.ac.uk/dpuprojects/drivers_urb_change/urb_society/pdf_liveli_vulnera/ifpr i_garett_food_security.pdf [Accessed:11.05.2017].

Arslan M, Katipoğlu E. 2011. Kentsel çevrede yaşlı kişilerin sağlı̆̆ ve etkinlikler için bitki yetiştiriciliğinin önemi. Yaşlı Sorunları Araştırma Dergisi, 4(1-2);44-52.

Beach M. 2013. Urban Agriculture Increases Food Security for Poor People in Africa, Population Reference Bureau. http://www.prb.org/Publications/Articles/2013/urbanagriculture-poor-africa.aspx [Accessed:10.06.2017].

Chen S, Ravallion M. 2007. Absolute Poverty Measures for the Developing World, 1981-2004. Policy Research Working Paper 4211. World Bank. Washington DC. https://openknowledge.worldbank.org/handle/10986/7060 [Accessed:25.04.2017].

Corbould C. 2013. Feeding the Cities: Is Urban Agriculture the Future of Food Security?. Future Directions International. Strategic Analysis Paper. http://futuredirections.org.au/wpcontent/uploads/2013/11/Urban_Agriculture-_Feeding_the _Cities_1Nov.pdf [Accessed:08.05.2017].

Coronel AS, Feldman SR, Jozami E, Facundo K, Piacentini RD, Dubbeling M, Escobedo FJ. 2015. Effects of urban green areas on air temperature in a medium-sized Argentinian city. AIMS Environmental Science, 2(3); 803-826.

ECOSOC 2014. Some facts on urbanization. http://www.un.org/en/ecosoc/integration/pdf/fact__ sheet.pdf [Accessed:17.04.2017].

FAO 2007. Profitability and sustainability of urban and peri-urban agriculture. by René van Veenhuizen and George Danso. http://www.ruaf.org/sites/default/files/Profitability $\% 20$ and\%20Sustainability.pdf [Accessed:30.04.2017].

FAO 2010. Growing Greener Cities. http://www.fao.org/ ag/agp/greenercities/pdf/ggc-en.pdf [Accessed:22.05.2017].

FAO 2016. Benefit of Urban Tree. http://www.fao.org/ resources/infographics/infographics-details/en/c/411348/ [Accessed: 01.06.2017].

Guang X. 1997. An Estimate of the Economic Consequences of Environmental Pollution in China. Policy Research Center of the National Environmental Protection Agency. http://www.homerdixon.com/projects/state/chinaeco/pollut.htm [Accessed: 10.06.2017].

Gün S. 2014. Köylerin ve Kırsal Alanın Yeniden Tanımlanması Sürecinde Tarım Topraklarının Kullanımı ve Korunması. 11. Ulusal Tarım Ekonomisi Kongresi. 3-5 Eylül, Samsun, Cilt 1; 473-478.
House WJ, Ikiara GK, McCormick D. 1993.Urban SelfEmployment n Kenya: Panacea or Viable Strategy? World Development, 21(7);1205-1223.

IDRC 1994. Cities Feeding People - An Examination of Urban Agriculture in East Africa, https://idl-bnc.idrc.ca/ dspace/bitstream/10625/9824/35/IDL-9824.pdf [Accessed:02.05.2017].

ILO 2013. Labour Issues in Urban and Peri-Urban Agriculture: Information and Resource Guide. International Labour Office. Sectoral Activities Department, Geneva.

Kisner C. 2008. Green Roofs for Urban Food Security and Environmental Sustainability. http://climate.org/archive/ topics/international-action/urban-agriculture.htm [Accessed: 15.05.2017].

Korir SCR, Rotich JK, Mining P. 2015. Urban Agriculture And Food Security in Developing Countries: A Case Study of Eldoret Municipality, Kenya. European Journal of Basic and Applied Sciences, 2(2); 27-35. http://www.idpublications.org/ ejbas-vol-2-no-2-2015/ [Accessed:20.05.2017].

Marras S. 2014. Street food and urban and periurban agriculture and horticulture: perspectives for a strategic coalition towards food security. http://www.fao.org/fsnforum/activities/discussions/ Street-food-UPA [Accessed:15.05.2017].

Monaco F, Zasada I, Wascher D, Glavan M, Pintar M, Schmutz U, Mazzocchi C, Corsi S, Sali G. 2017. Food Production and Consumption: City Regions between Localism. Agricultural Land Displacement, and Economic Competitiveness. Sustainability. 9(1) 96, http://www.mdpi.com/20711050/9/1/96/htm [Accessed:15.06.2017].

Mougeot LJ. 2000. Urban agriculture: definition, presence, potentials and risks. Growing cities, growing food: Urban agriculture on the policy agenda, 1-42.

Mougeot LJA. 2006. Growing Better Cities: Urban Agriculture for Sustainable Development (In Focus). International Development Research Centre. http://idl-bnc.idrc.ca/dspace/ bitstream/10625/30554/

[Accessed:30.04.2017].

Orsini F, Kahane R, Nono-Womdim R, Gianquinto G. 2013. Urban Agriculture in the developing world: a review. Agronomy for sustainable development, 33(4); 695-720.

Pothukuchi K. 2015.Urban Agriculture Policy in Detroit History and Prospects. In M. H. Chumbler, S. E. Negro, and L. E. Bechler, eds., Urban Agriculture: Policy, Law, Strategy, and Implementation. Chicago: American Bar Association. Article on State and Local Government Law, 279-298, http://www.clas.wayne.edu/Multimedia/clas.wayne.edu/Files/ Pothukuchi\%20urban\%20ag\%20chapter.pdf [Accessed:10.05.2017].

Requier-Desjardins D, Boucher F, Cerdan C. 2003. Globalization, competitive advantages and the evolution of production systems: rural food processing and localized agri-food systems in Latin-American countries. Entrepreneurship \& Regional Development, 15(1);49-67.

Silverman D, Bolin DJ. 2014. Stockyards to Backyards:Local Food Production in Chicago's Urban Jungle. Chapter 14. Urban agriculture, 253-277. http://www.americanbar.org/content/ dam/aba/administrative/state_local_government/UrbanAgricultu re71515.authcheckdam.pdf [Accessed:09.05.2017].

Simatele DM. Binns T. 2008. Motivation and Marginalization in African Urban Agriculture. Urban Forum, 19(1):1-21.

Smit J, Nasr J, Ratta A. 2001. Urban agriculture: food, jobs and sustainable cities-2001 Edition. Chapter 10 Trends in Urban Agriculture. United Nations Development Programme (UNDP, http://jacsmit.com/book/Chap10.pdf [Accessed:26.04.2017].

Stewart R, Korth M, Langer L, Rafferty S, Da Silva NR, van Rooyen C. 2013. What are the impacts of urban agriculture programs on food security in low and middle-income countries?. The official journal of the Collaboration for $\begin{array}{ll}\text { Environmental } & \text { Evidence, }\end{array}$ http://environmentalevidencejournal.biomedcentral.com/articles /10.1186/2047-2382-2-7 [Accessed:29.04.2017].

Topçu P. 2012. Tarım Arazilerinin Korunması ve Etkin Kullanılmasına Yönelik Politikalar. Uzmanlı Tezi. T.C. Kalkınma Bakanlığı Yayın No.2836, Ankara. 
UN 2014. United Nations. Department of Economic and Social Affairs, Population Division (2014). World Urbanization Prospects: The 2014 Revision, CD-ROM Edition. https://esa.un.org/unpd/wup/cd-rom/ [Accessed: 04.04.2017].

UN-HABITAT 2010a. Urban Trends: 227 Million Escape Slums. http://mirror.unhabitat.org/documents/SOWC10/R1.pdf [Accessed:04.04.2017].

UN-HABITAT 2010b. State of the World's Cities 2010/2011 Bridging The Urban Divide. https://unhabitat.org/books/stateof-the-worlds-cities-20102011-cities-for-all-bridging-the-urbandivide/ [Accessed: 04.04.2017].

UN-HABITAT 2013. Streets as Public Spaces and Drivers of Urban Prosperity. https://unhabitat.org/books/streets-as-public-spacesand-drivers-of-urban-prosperity/ [Accessed: 04.04.2017].

UN-HABITAT 2014. WHD Background Paper. https://unhabitat.org/wp-content/uploads/2014/07/WHD-2014Background-Paper.pdf [Accessed: 04.04.2017].

Viocu I, Been V. 2008. The Effect of Community Gardens on Neighboring Property Values. Real Estate Economics, 36 (2);241-283. http://furmancenter.org/files/publications/The _Effect_of_Community_Gardens.pdf [Accessed:22.05.2017].
WORLDBANK 2012. Poverty and Food Price Developments Chapter 1. Food Prices Nutrition and the Millennium Development Goals. Global Monitoring Report. http://siteresources.worldbank.org/INTPROSPECTS/Resources/ 334934-1327948020811/8401693-1327957211156/84024941334239337250/Chapter-1.pdf [Accessed:10.05.2017].

Yenigül SB. 2016. Büyükşehirlerde Tarımsal Alanların Korunmasında Kentsel Tarım ve Yerel Yönetimlerin Rolü. Megaron,11(2):291-299. https://www.journalagent.com/ megaron/pdfs/MEGARON_11_2_291_299.pdf [Accessed:29.06.2017].

Yoveva A, Gocheva B, Voykova G, Borissov B, Spassov A. 2000. Sofia: urban agriculture in an economy in transition. In: N. Bakker, M. Dubbeling, S. Guendel, U. Sabel Koschella \& H. de Zeeuw, eds, Growing cities, growing food: urban agriculture on the policy agenda. A reader on urban agriculture, 501-518. 